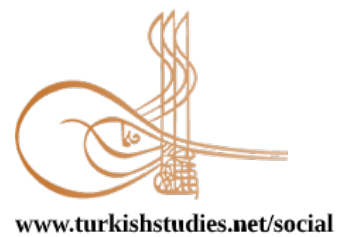

Turkish Studies - Social Sciences

\title{
Osmanlıdan Günümüze Değişen Kent İmgesinin Sanatçıların Eserlerine Yansıması*
}

\author{
The Reflection of the Change in City Image from Ottoman Era to Our Day on the Artworks of \\ Artists
}

\author{
Nuri Özçelik ${ }^{* *}$
}

\begin{abstract}
Cities have always been one of the most essential parts of civilizations as they've hosted individuals that resided in those cities hence spending most of their lifetime in those areas. Such formation has also affected artists as resident in the city by the context of image. Thus, the city has been the subject to the art of painting with the elements and visual codes it contains as well as its physical structure and dynamics, taking part in various fictional pictorial compositions throughout the time. In this study, the physical structure of the 19th century Ottoman period cities was presented under the first title, the architectural structures, houses, streets in the cities, which are the social life spaces of the period, were investigated in the light of physical sources, and the ways of reflection of the artists of the period in the context of plastic were investigated. In the second title, this review and presentation process took place over today's cities, and comparisons and examples were preferred at this stage. The goal of this research is to examine the changes in the appearance of the 19. Century Ottoman type cities to the contemporary city of today by the context of image, through examples in the art of painting. During this review process - within the art of painting that kept ever-changing along with the altered dynamics of the world - the reflection of city image upon the pictorial art is taken into consideration through interferences over the works of artists bounded by the related era. Thus; in order to make contribution to the literature, through the examples, the way that 19. century Ottoman cities were addressed by the painters is compared to the reflection of contemporary cities on pictorial plane and it was observed that the cities where individuals resided have periodically affected artist's personal art life.
\end{abstract}

Structured Abstract: In the history of art, it has been seen that the cities representing civilization, housing, and sometimes power are handled by painters. The fact that cities, which are the center of housing and civilization, are subject to art and their depiction by artists have been important both in terms of an aesthetic interpretation plane and a document that is noted in history. When looking at European art, many city depictions were used in the art of painting with different pictorial style interpretations in Ancient Greece and Rome. In the Ottoman period, the first examples appear in miniature art and in wall paintings applied in the interior. Houses, collective living spaces, neighborhoods, cities, which form in artistic planes, where the individual lives, are interpreted differently in the pictorial plane, and sometimes they are interpreted as part of

\footnotetext{
* Bu makale, “1980'den günümüze çağdaş Türk resminde kent imgesi” adlı sanatta yeterlilik tezinden, tez danışmanı Prof. Rıdvan Coşkun önderliğinde Nuri Özçelik tarafından üretilmiştir.

** Resim Öğretmeni, İsmek, M.E.B.

Art Teacher, İsmek, Ministry of Education

ORCID 0000-0002-2399-7363

ozcelik.nuri@hotmail.com

Cite as/ Atıf: Özçelik, N. (2020). Osmanlıdan günümüze değişen kent imgesinin sanatçıların eserlerine yansıması.

Turkish Studies - Social, 15(4), 2099-2112. https://dx.doi.org/10.29228/TurkishStudies.42662

Received/Geliş: 26 March/Mart 2020

Accepted/Kabul: 20 June/Haziran 2020

Checked by plagiarism software

Copyright (C) INTAC LTD, Turkey

Published/Yayın: 25 June/Haziran 2020

CC BY-NC 4.0
} 
a landscape that is sometimes seen, sometimes as a form that shapes the psychology and lifestyle of the person.

This research has covered the works of the 19th century Ottoman cities and the period painters who dealt with the appearance of our cities from the 2000s to the present. Based on selected examples, he evaluated the reflections and styles of the painters carrying the urban views to his works in the Ottoman period canvas painting, reviewing his works on the canvas dating back to $2000 \mathrm{~s}$, and the way the artist depicts the cities in which he lives and lives. The problem here is that the 19th century Ottoman cities and today's cities covering 2000s are transferred to the pictorial plane as images. The aim of the subject is to contribute to both the individual art process and the area in which the research was carried out due to the author's work on the city.

In the process of work, the methods of explanation, sampling and comparison have been advanced, and the analysis of the works, the period of the art object, the cultural characteristics of the period, the effect of the cultural environment on the work of art, and the contribution of the artist's personality to the work of art, are analyzed through the iconological analysis method, and the resulting data are evaluated. It was presented by passing the stage. In this historical period, the city views were interpreted in the light of the artistic dynamics of the period, and the reflections of the city views to the works of the city painters were presented in a comparative, sociological and pictorial perspective.

Since the cities contain the definition of civilization and collective living, it meets the asylum and survival needs of human life. These living spaces, where the individual is in, have become an indication of identity as well as being a place that is lived only in time. Cities with identity; When it is examined according to physical and historical variables, it has been the subject of the artist's brush, which is one of the individuals living in it, sometimes with its religious structures, sometimes with its magnificent buildings and sometimes with its physical fictional structure.

As can be understood from the works handled within the framework of the research; The artists of the period (Hoca Ali Riza, Salih Bey, Fehmi Bey), who expressed what is unique to their age as children of their age, carried the Ottoman settlements, sociological life and urban structuring to their works (Albayrak, 2012:75). Descriptions of the works of this period have been pursued in a sense of style formed in a realistic and impressionistic plane due to the artistic dynamics of the period, and could not go beyond the idealized forms of art that are concerned about reflecting the visible. As it can be understood from the donors presented in the study, the cities of the Ottoman period have a horizontal appearance within the architectural understanding of the period and the urbanization policy of the houses with low floors. Contrary to today's vertical structure, it can be seen that the urban structure of the Ottoman Empire in the horizontal plane reflected in the same way and was a source for the works produced in that period. The cause-effect relationship in the equation of the inference here can be explained by the physical structure of the Ottoman period architecture and the production of works based on the existing indicators within the framework of the artistic understanding of the painters living in the society. In other words, the painters, who included the appearance of the Ottoman cities in their artistic process, transferred the frosts they encountered in the existing urban plane - mosques with the highest structure, earth roads, wooden houses not exceeding two or three times, and neighborhood fountains.

Considering the works and the inferences made within the artists in the research; There were some variations in the physical, social, sociological and architectural contexts between the urban views of the Ottoman period and the contemporary urban views. While today's cities have grown and visual stimuli that can be counted in the Ottoman period are in a plane that does not exceed five fingers of a hand in the form of street lights, houses, mosques, tram, metro, airrail their wires, poles, stations, side streets, streets, highways, bridges, cars, trucks, lorries, freight ships passing through the Bosphorus, ferries, coast guard boats, large and small private yachts, slums, shopping malls, plazas, ordinary apartments, mansions, traffic signs, billboards etc. It was filled with many indicators and changed.

Like urban differences formed in the last century, they differed in artists, and their understanding of art also changed. It has been seen that today's painter carries urban views, which offer data on different planes with many dynamics. The buildings, streets, street lights, cars in heavy traffic and the constructions created by them, which are not attributed to any citizen, are very important artistic elements of the pictorial plane for the artist. In the process of formation, the process of interpretation was initiated by considering the stylistic differences within the modern art movements of the period. While today's artist carries urban forms 
to his works, he also incorporated his original interpretation touches and affective processes. Contrary to the period painters who carried the urban appearance of the Ottoman period to their works, the city, which was present in the works of the artists (Mustafa Duymaz, Canan Tolon, Altan Çelem, Hakan Gürsoytrak, Antonio Cosentino), based on the desire of reflecting the visible with the analogy of the city, the artists formed in a plane beyond the desire to reflect the visible. They have created their own cities in their works, and have critically expressed their individual perspectives through their mental emotional filters, and took the views of today's cities as subjects in their plastic processes.

In the direction of the data obtained, when the pictures of the artists reflecting the realities of the time they lived in were compared, it was seen that the essence appeared in a different language in every period and in every artist. The artists produce their works in an effort to reveal and change the social and cultural values that are valid during the creation process with many different artistic tendencies according to the period they are in (Edeer, 2015: 29). The city, which we encounter in the narratives on the artistic plane, has taken its place as a pictorial element, with or without motivation of the analogy of the analogy.

Keywords: City, Artist, Painting, Image, Ottoman

Öz: Kentler, bireyin içinde barındığı, hayatını sürdürdüğü, uygarlığın en önemli yaşam alanlarından biri olmuştur. Bireyin içinde yaşadığı bu oluşum, imge bağlamında kentin içinde yaşayan bir birey olarak sanatçıyı da etkilemiştir. Böylelikle kent; içinde barındırdığı ögeleri ve görsel kodları, fiziki yapısı, dinamik haliyle resim sanatına konu olmuş ve resimsel kompozisyonların kurgularında yer almıştır. Bu çalışmada, birinci başlık altında 19. yüzyıl Osmanlı Dönemi kentlerinin fiziki yapısı genel olarak sunulmuş, dönemin toplumsal yaşam alanı olan kentlerin içinde bulunan, mimari yapılar, evler, sokaklar fiziki açıdan kaynaklar ışığında incelenmiş, dönem ressamlarının eserlerine plastik bağlamda yansıyış biçimleri araştırılmıştır. İkinci başlıkta ise bu inceleme ve sunum süreci günümüz kentleri üzerinden olmuş, bu aşamada karşılaştırmalar, örneklendirmeler tercih edilmiştir. Bu araştırmanın amacı; 19. yüzyıl Osmanlı dönemi kentleri ile günümüz kentlerinin imge bağlamında, görünüm olarak değişime uğrayış süreçlerini resim sanatındaki örnekler üzerinden incelemek olmuştur. Bu inceleme sürecinde, değişen dünyanın dinamiği ile birlikte değişen resim sanatı içerisinde, dönem sanatçılarının eserleri üzerinden çıkarımlar yapılarak belirlenen dönemlerde resim sanatına kent imgesinin yansıması ele alınmıştır. Böylelikle, literatüre katkı sağlamak amacı ile 19. yüzyıl Osmanlı kentlerinin ressamlar tarafından ele alınışı ve 2000'li yıllardan sonrasını kapsayan bir süreçte günümüz kentlerinin resimsel düzleme yansıyışı örneklerle karşılaştırılmış ve bireyin yaşadığı kentlerin sanatçının kişisel sanat hayatına dönemsel olarak farklı şekilde etki ettiği gözlemlenmiştir.

Anahtar Kelimeler: Kent, Ressam, Resim Sanat, İmge, Osmanlı

\section{Giriş}

Sanat tarihinde, uygarlığın, barınmanın, kimi zaman da gücün temsili olan kentlerin ressamlar tarafından ele alındığı görülmüsstür. Barınmanın ve uygarlığın merkezi olan kentlerin sanata konu edinilmesi, sanatçılar tarafindan betimlenmesi hem estetik bir yorumlama düzlemi, hem de tarihe not düşülen bir belge olması açısından önemli olmuştur. Avrupa sanatına bakıldığında, Antik Yunan ve Roma'da birçok kent tasviri farklı resimsel üslup yorumlamalarıyla resim sanatında kullanılmıştır. Osmanlı döneminde ise ilk örnekler minyatür sanatında ve iç mekanda uygulanan duvar resimlerinde karşımıza çıkmaktadır. Sanatsal düzlemlerde biçim bulan, bireyin içinde yaşadığı evler, toplu yaşam mekanları, mahalleler, kentler Osmanlı döneminde farklı, günümüzde ise farklı şekilde resimsel düzlemde yorumlanarak, kimi zaman sadece görülen bir manzaranın parçası kimi zaman ise insanın psikolojisine, yaşam biçimine şekil veren bir oluşum olarak yorumlanmıştır.

Bu araştırma kapsam olarak 19. yy. Osmanlı kentlerinin ve 2000'lerden günümüze olan periyoddaki kentlerimizin görünümünü konu edinen dönem ressamlarının eserlerini ele almıştır. Seçilmiş örnekler üzerinden Osmanlı dönemi tuval resminde kentsel görünümleri eserlerine taşıyan ressamların yansıtma şekillerini ve üsluplarını değerlendirmiş, 2000'lerden sonrasına tarihlenen tuval üzerine olan eserleri ile günümüz ressamının kentsel görünümleri eserlerine yansıtma 
şekillerini gözden geçirerek, sanatçının içinde bulunduğu, yaşamını sürdürdüğü kentleri betimleyişlerini incelemiştir. Burada problem edinilen durum, 19.yy. Osmanlı kentleri ile 2000'lerden sonrasını kapsayan günümüz kentlerinin imge olarak resimsel düzleme aktarılış şekilleridir. Konunun amacı yazarın kendisinin de kent ile ilgili çalışmalar yapmasından kaynaklı olarak hem bireysel sanat sürecine hem de araştırmanın yapıldığı alana katkılı olabilmektir.

Çalışma sürecinde açıklama, örneklendirme ve karşılaştırma yöntemleri üzerinden ilerlenmiş, eserlerin analiz sürecinde de sanat nesnesinin oluştuğu dönem, dönemin kültürel nitelikleri, kültürel ortamın sanat eserine etkisi, sanatçının kişiliğinin sanat eserine katkısı önemsendiği için genel hatlarıyla ikonolojik analiz yöntemi üzerinden çözümlemeler yapılmış, ortaya çıkan veriler değerlendirme aşamasından geçirilerek sunulmuştur. Bu çerçevede ele alınan kaynaklardan yararlanılarak kent görümleri ait olduğu tarihsel periyotta, içinde barındırdığı dönemin sanatsal dinamikleri 1şı̆̆ında yorumlanmış, elde edilen bulgular ile kent ressamlarının eserlerine kent görünümlerinin yansıyış biçimleri yer yer karşılaştırmalı bir biçimde, sosyolojik ve resimsel bir perspektiften sunulmuştur.

\section{Osmanlı Dönemi Kent Görünümleri Ve Dönem Resim Sanatında Kullanımı}

Kentler; dünya üzerindeki uygarlıklar, topluluklar, kitleler, büyük ulusları oluşturmaya başladığında, temel barınma ihtiyacının ötesine geçerek, bilgi, güç, zenginlik gibi önemli amaçlara, kavramlara hizmet etmeye başlamıştır. Mısır'da piramitlerin, Mezopotamya'da Babil kulesinin yapılması gibi kentlerin tasarımında, uygarlıkların ekonomik, siyasi, dini, kültürel, sosyal temsilleri devreye girmiştir. Uygarlıkların temsili olan, kentler içinde yaşayan toplumun özelliğini alan ve zamanla toplumun yaşam tarzına göre değişen bir yapıda olmuştur. Bu değişim o toplumun yaşam tarzına göre, farklılıklar gösterebilmektedir. Her toplum kendi izlerini, kendi dini inanışlarını, mimari anlayışlarını, toplumsal yaşam tarzlarını kentlerine yansıtmıştır. Osmanlı İmparatorluğu da diğer medeniyetler gibi hem kendine miras kalanlarla hem de kendi toplumsal yaşam tarzlarıyla kentlerin karakterini etkilemiştir.

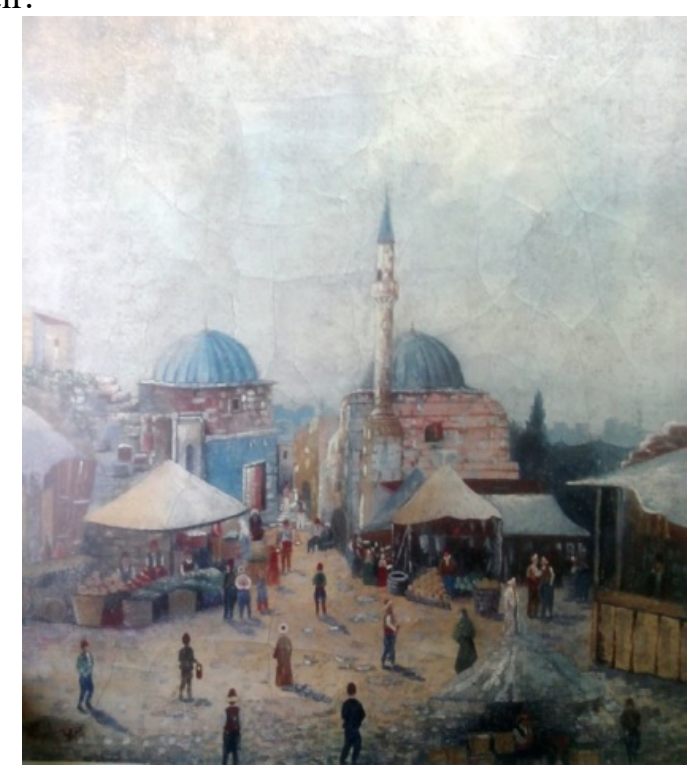

Görsel 1. Fehmi, "Osmanlı Pazar Yeri-İstanbul”, $44 \mathrm{~cm}$ x $39 \mathrm{~cm}$, Tuval üzerine yağlı boya,19.yy, Dolunay Yalçın Koleksiyonu (Renda, G. Erol, T. 1980)

Osmanlı dönemi kentleri, günümüzde metropol, megakent gibi içinin birçok içerikle dolu olduğu yoğun kent kavramı tanımlamasının aksine, köyden büyük olan, pazarı, çarşısı, merkezi bir yerleşim alanına sahip olan bir yapıda tanımlanmıştır (Özbilgen, 2014: 377). 19. yüzyıla yani; Osmanlı sanatının modern dönemlerine ait olan "Osmanlı Pazar Yeri-İstanbul" adlı eserden de anlaşılacağı üzere; dönemin en yüksek yapıda olan mimari oluşumu, günümüz gökdelenlerinin 
aksine camilerdir. Osmanlı döneminin kentsel anatomisinin sunulduğu bu eserde sanatçı, gerçekçi bir yorumlamayla kendi gözünden İstanbul'un bir pazar yeri görüntüsünü sunarak kentin fiziki yapısını betimlemiştir. 19. yy'a tarihlenmiş bu yağlıboya eserin yapıldığı dönemlerde fotoğraf makinasının icadının, kullanımının söz konusu olmadığı ve dönemin mevcut sanat anlayışı göz önünde bulundurulduğunda gerçekçi bir yorumlama düzleminde dokunuşlar yapılması şaşırtıcı değildir. Sanatçı görünen ile gösterilmek istenilen arasındaki ince çizgiyi aşmadan natüralist dokunuşlarla anın belgesini sunmuştur (Görsel 1).

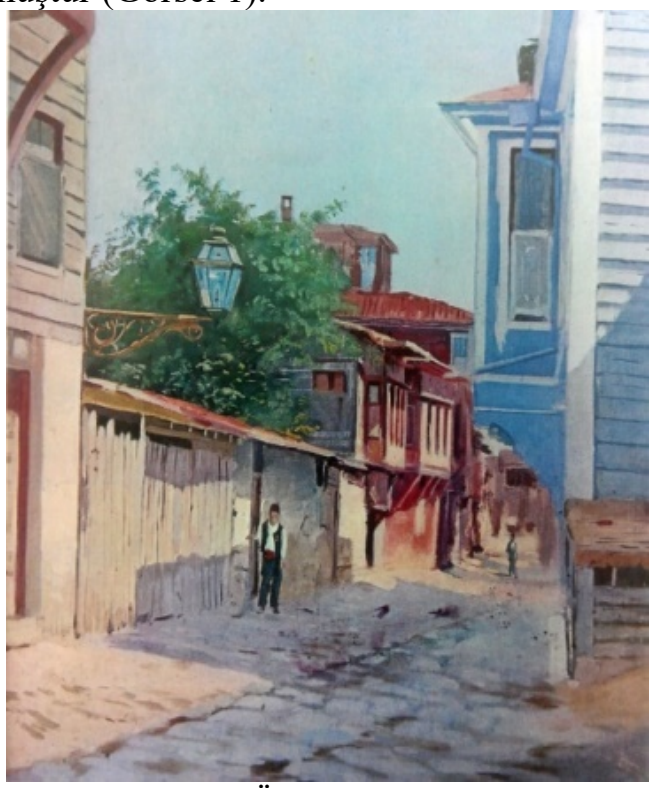

Görsel 2. Hoca Ali Rıza, ’Fenerli Sokak Üsküdar", $32 \mathrm{~cm}$ x $42 \mathrm{~cm}$, Tuval üzerine yağlı boya, İstanbul Resim ve Heykel Müzesi, 1867 (Renda, G. Erol, T. 1980)

Resim sanatı var oluş sebebiyle, betimleme bağlamında kullanılan ve betimlenme aşamasında sanatçının belleğindeki süzgeçten geçerek, duygularla yoğrulan bir düzlemde sonuca ulaşan bir süreci içerir. Burada üretimin başat rolünde olan sanatçı içinde olduğu dönemin, toplumsal yapının, sanatsal anlayışına göre hareket etmiştir. Osmanlı dönemi ressamları arasında yer alan Hoca Ali Rıza genel olarak resmettiği doğa betimlemelerinin yanı sıra birkaç eserinde dönemin kentlerinden kesitler sunmuştur. Mahalle yaşamından bir anı betimleyen, bu tanımlamayı oluştururken dönemin gerçekçi-izlenimci sanat anlayışına sadık kalan, sanatçı dönemin kentsel ögelerini belgelemiştir. Lirik firça dokunuşlarıyla betimlediği bu eserde dönemin evlerinin yapısını, sokak anlayışını, mimari düzenini mahalli bütünlükte resmetmiştir (Görsel 2).

Osmanlı'da 19.yy'da eser veren dönem sanatçılarının eserlerinden de anlaşılacağı üzere; Osmanlı kentlerinin yapısını oluşturan birçok bileşenden biri, Osmanlı kentlerinin genel fiziki yapısını oluşturan mahalle kavramıdır. Mahalle, İstanbul ile imparatorluğun diğer büyük kentlerinin fiziksel yapısının en temel birimidir (Shaw, 1994: 228). Bu yapı, günümüzde daha çok bir alışveriş merkezinin, bir havaalanının ya da bir iş merkezinin çevresinde yer almaktayken Osmanlı'da bir pazarın etrafında ya da bir dini yapının etrafında meydana gelmiştir (Doğru, 1995: 106). Günümüzde birbirini tanımayan bireylerin birlikte olduğu bir oluşum olan mahalle, Osmanlı sistemi içinde mekan ve yaşam alanı olarak toplumsal ortaklığın ve paylaşımın oluştuğu alanlardır (Kılıçbay, 2000: 46). 


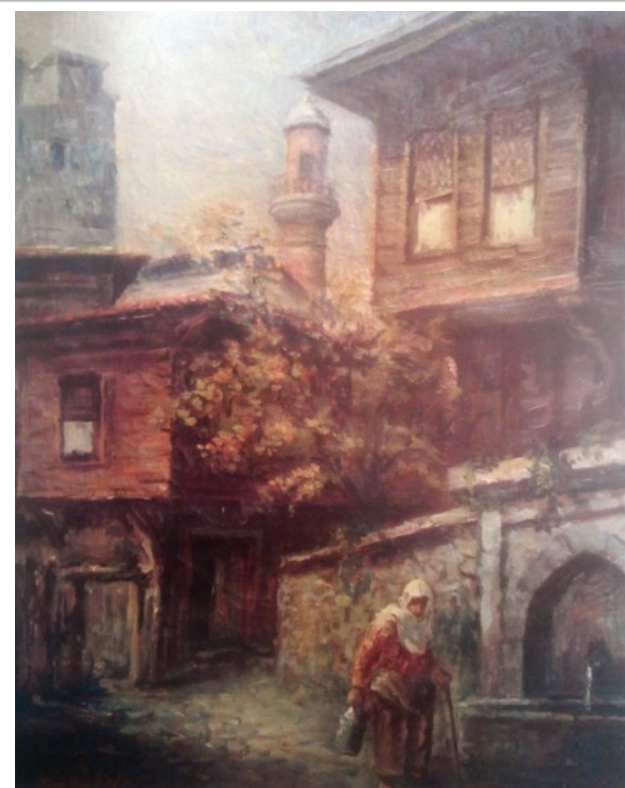

Görsel 3. Salim, “Üsküdar'da Sokak”, $35 \mathrm{~cm}$ x $45 \mathrm{~cm}$, Tuval üzerine yağlı boya, Elif-Boyvadaoğlu Koleksiyonu (Renda, G. Erol, T. 1980)

Osmanlı dönemi sanatı özellikle 19 yy'a doğru yağlıboya ve tuval resmi bağlamında önemli örneklerini vermeye başlamış, dönem ressamları yabancı ressamlardan öğrendiklerini çağının gereklilik ve gerçekleri dahilinde işlemişlerdir. İstanbul'un Üsküdar semtinden bir kesitin izlenimci bir yorumlama ile gerçek formlardan uzaklaşmadan sunulduğu bu eserden de anlaşılacağ üzere Osmanlı'da kent tanımlamasında önemli oluşum sokaktır. Günümüzdeki bir tarafı yerel yönetimler tarafından kullanıma açılmasıyla araç parklarına ait olan, diğer tarafta seyir halinde olan araçlardan adım atılmayan, daracık kaldırımlarıyla akılda yer eden sokak oluşumunun aksine bu yapılar, bu eserde de kullanıldığı gibi genelde yayaların kullanımın ağırlıkta olduğu, dönemin ilkel araçlarının kullandığı, taşlarla döşenmiş bir formda karşımıza çıkmaktadır (Özbilgen, 2014: 389). (Görsel 3) Bugünkü anlamda bulvar ya da cadde yapılanmaları ile de karşılaşılmayan dönemin sokaklarında 1850 'lere kadar kaldırım formunda bir yapılanmaya bile rastlanmadığı için bu esere yansıdı ğ haliyle figür yolun ortasında resmedilmiştir.

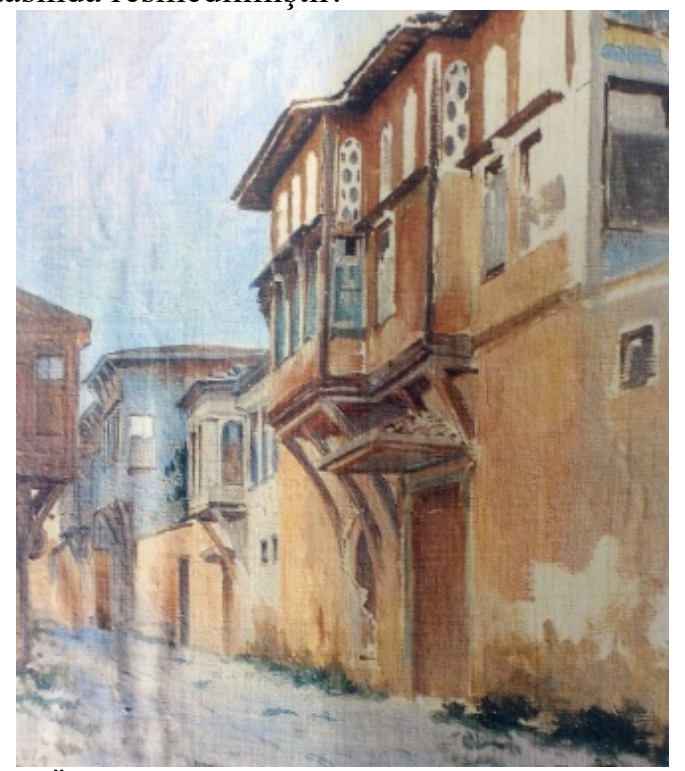

Görsel 4. Hoca Ali Rıza, “Üsküdar’dan Pembe Ev”, 39 cm x 30,5 cm, Tuval üzerine yağlı boya, 1908 (Renda, G. Erol, T. 1980) 
Hoca Ali Rıza'nın bu eserinde de işlendiği üzere; Osmanlı'nın toprak yollu, yer yer yol kenarlarında otlanmaların da oluştuğu sokaklarının yanlarını dolduran yapılar günümüze de miras kalan konaklar, köşkler, cumbalı evlerdir (Görsel 4). Evlerin genel özelliği, günümüz evlerinin kar gütme amaçlı dikey büyüyen apartmanların içine $1+1$ ya da stüdyo daire olarak yapılmasının aksine, bir veya iki katll, müstakil, geniş, ferah, büyük bir ailenin yaşayabileceği düzende inşa edilmiş olmasıdır. Osmanlı evleri geniş ve yüksek kapılarıyla ince-uzun sokağa doğru açılır, evler bahçe içindedir, Osmanlı'nın ekonomisinin genel olarak tarımsal faaliyetlere dayalı olmasından kaynaklıdır ki, evlerin alt katları erzak-eşya saklamak, ev sahibinin hayvanlarına barınak olmak gibi amaclarla kullanılmıştır (Doğru, 1995: 110). Alt katlar genelde küçük pencerelerle, sağır ve yüksek duvarlarla örülüdür bu da Batı kültüründeki evlerin dışa açılmaları ve dışa doğru büyümeleri durumunun aksine Osmanlı evlerinin içe doğru büyüyen bir anlayışta düzenlendiğine işaret eder (Özbilgen, 2014: 386). Kapalı bir kent modelinde olan Osmanlı kentlerinin ortasında bir cami veya külliye ve çevresinde pazarlar ve yerleşim alanları bulunduğu bilinmektedir (Özcan, 2006: 44). Cami dışındaki yapıların genel olarak iki ya da bir katlı bağımsız evler biçiminde konumlandırılmasından ve her evin bir bahçesi olması ve bahçenin içinde de en az bir ağaç dikili olmasından kaynaklıdır ki Osmanlı kent görünümleri, günümüzdeki kentlerin uzaktan bakıldığında gri bir yığın, beton bir orman olarak görünmesinin aksine, yeşillikler içinde algılanır.

Her dönem içinde bulunduğu çağ ile mevcut (teknolojik) gelişmeleri ile değişen yaşam biçimleri, yaşam biçimlerinin içinde barındırdığı karşıtlıkları, benzerlikleri ve görsel kodları ile okunmalı ve değerlendirilmelidir. Çağının ressamı bu anlamda insanı ile arabasılyla, anteni ile ya da duvarda kalan bir yırtık afişi ya da balkonundaki eşyalarıyla da olsa yaşadığı toplumla bir bağ kurmaktadır. Yaşadığı toplumun içinde sanatçının belleği birçok uyaranla karşılaşmaktadır, bu bağlamda bakıldığında sanatçıyı yaşadığı toplumun değişimlerinden etkilenen, eserlerinde de kullanan birey olarak yorumlayabiliriz. Çevresel faktörler, sanatçının dünya görüşünü genişlettiği gibi O'nun ifade zenginliğini çoğaltıcı, özendirici, oluşumları değerlendirmeye yöneltici bir işlevde sunar. Çevresinden etkilenen sanatçı, Osmanlı döneminde belli otoritelerin gölgesi altında ve dini inanışın sınırları çerçevesinde eserler üretmiş, dönemin kentsel yapılanmasını belgecilik düzeyinde de olsa eserlerine taşımıştır. Özgün yorumlama, biçim bozma ya da yeniden yaratma gibi süreçlere girmeyen Osmanlı ressamları, gerçek yaşamda gördüklerini ya da otoriteler tarafindan görülmesi istenileni yansıtmışlardır. Resmettikleri eserlerdeki imgelerde dönemin kentlerinin fiziki yapısı hakkında görsel kodlar sunmuştur.

\section{Günümüz Kentleri Ve Resim Sanatında Yer Alıșı}

Günümüz kentlerine ve resim sanatına bakılırsa ki burada bahsedilen günümüz atfının 2000'lerden sonrasını kapsadığını dile getirmekte fayda bulunmaktadır. Aradan geçen bir asırlık dönemde, Osmanlı döneminin kapsadığ 1 altı asırlık dönemdeki kentsel ve sanatsal gelişmelerin değişimlerin toplamına oranla hızlı ve çok boyutlu değişimler oluşmuştur. Osmanlı döneminin kapanışının ardından geçen bir asırda, bir tarafta gökdelen gibi yüksek yapılar, aralarda kalan yalılar, diğer yanda bauhaus ekollü apartmanlar, bir diğer yanda da birbirinden tarz ve üslup olarak çok farklı, üst-orta tabakanın ikamet ettiği site oluşumları derken günümüz kentleri çok boyutlu, değiş̧ken, çok karakterli bir yapıya bürünmüştür. Bu yapı karşısında ressam ve sanatçıların kent ile ilgili üretimleri değişime uğramıştır. 


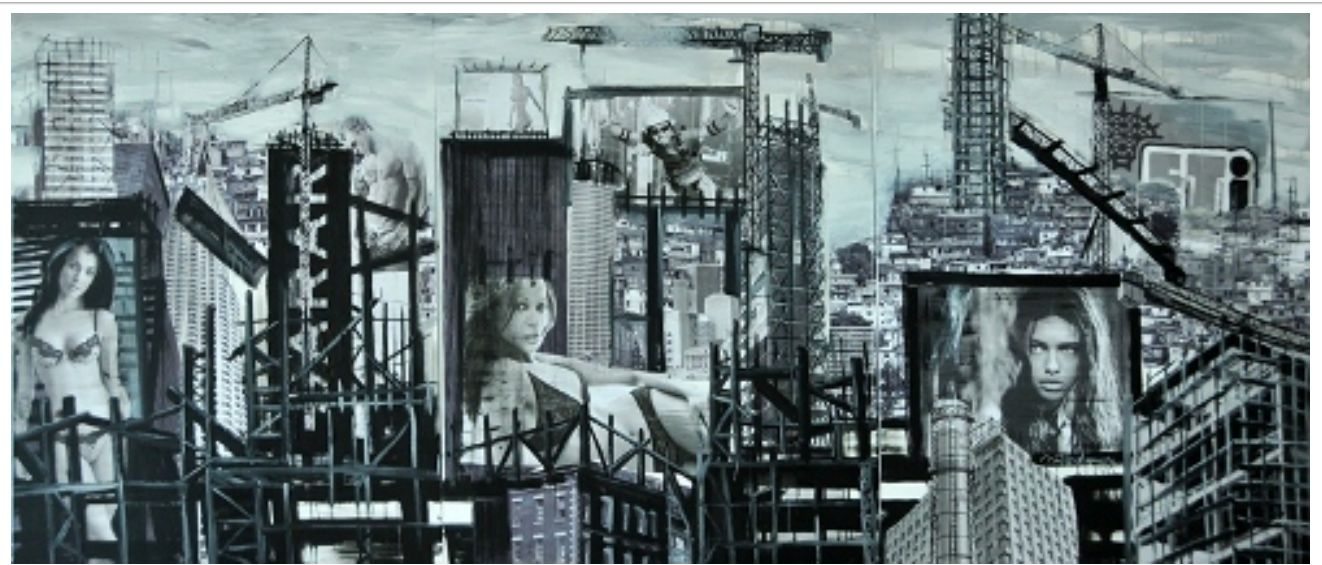

Görsel 5. Mustafa Duymaz, "Panokent”, Tuval üzerine karışık teknik, 2011 (Özçelik,2019).

Günümüz kentlerinin bu karma, değişken karakterli yapısı, içinde barındırdığı, kentin öğeleri olan inşaatlar, buralarda çalışan işçiler, inşaat makinaları, onların tozları, homurtuları, elektrik direkleri, telefon direkleri, gökdelenler, yoğun bina strüktürleri, reklam panoları gibi içerikler, tuval ya da farklı satıhlar üzerine yapılan üretimler ile Mustafa Duymaz'ın eserlerinde karşımıza çıkar (Tek,2014:3-Özçelik,2019:64). Kent ile alakalı kurgu resimlerde kadrajlanan, kentin simgeleri olan belli başlı yerleri, kentlerin gerçek düzlemde içinde barındırdığı eklektik yapısı gibi bir araya getirilmiştir. Bu konstrüksiyonların oluşum sürecinde kentin içinde barındığı sosyolojik karma yapıdan yola çıkılarak, boyasal plastik malzemelerin yanı sıra, kimi zaman kolajdan kimi zaman asemblajdan da yardım alınmış, kimi zaman da fotokopi makinalarından alınan devasa uzunlukta çıktılar ile tuval üzerine eserler üretilmiştir. Sanatçının eserlerinde çoğu zaman kenti donatan binalara rastlanırken bu binaların arasından fişkıran, kapitalizmi afişe eden devasa reklam panoları da görülebilir. Onun eserlerinde bitmeyen inşaatlarla değiş̧ime uğrayan, kapitalizmin, sömürünün, tüketimin yuvası olan büyük kentlerin değişimi, dönüşümü konu edilmiştir (Özçelik,2019:64). Durmaksızın göğe doğru yükselen binalar, bir sağa bir sola durmadan bir şeyler taşıyan devasa vinçler, onun resmettiği kent resimlerinin ana elemanları olarak karşımıza çıkmıştır (Görsel 5).

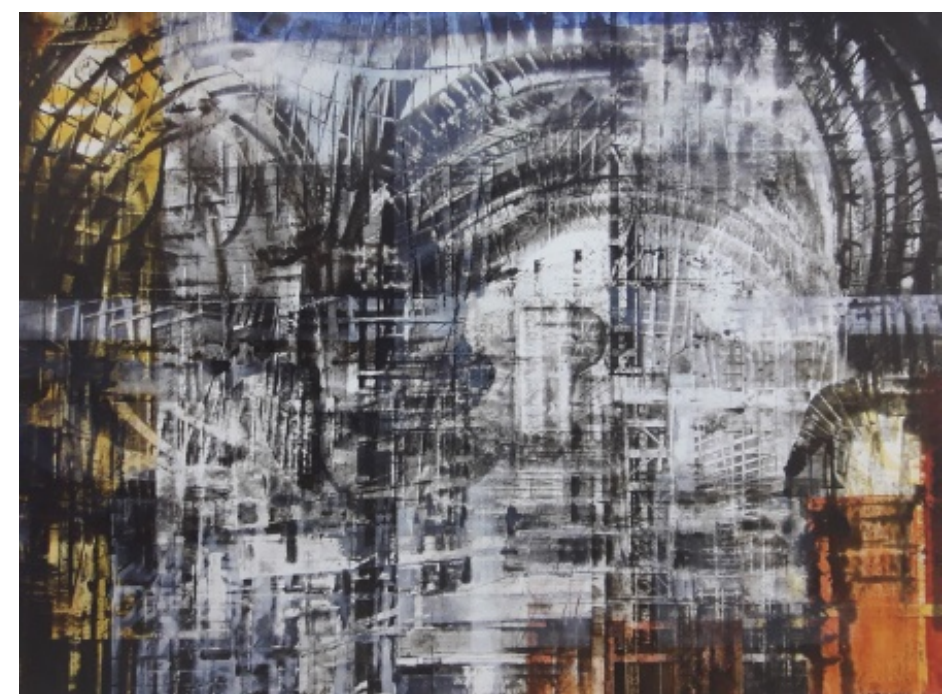

Görsel 6. Canan Tolon, "Glitch 2", $140 \mathrm{cmx} 180 \mathrm{~cm}$, Tuval üzerine yağlı boya, 2007, Tim ve Nancy Howes Özel Koleksiyonu (Antmen, 2002)

Değişken yapıda olan kent görünümlerini ele alan birçok sanatçı arasında, 2000'li yıllardan başlayarak eserlerinde kent ile alakalı ögeleri kullanan diğer sanatçı Canan Tolon'dur. Tolon'un çalışmalarında kent ile kurulan ilişki, mekân algısı üzerinden olmuştur. Bu mekânlar, fuar alanları, 
tren istasyonları, gökdelenler, apartmanlar gibi alanları temsilî olarak çağrıştıran imgelerdir (Antmen, 2002: 43). Güncel şehir manzaraları topografik görüntüler, Tolon'un eserlerine konu olmuş, eserlerin oluşum süreçlerinde de bu yapılarla alakalı verilerden yola çıkılmıştır. Genel olarak çalışmalarını kontrollü algısal bir soyutlama anlayışında günümüz kentlerinin yapısından etkilenen bir biçimde ilerletmiştir (Yayıntaş, 2008: 404). Mekansal, kentsel ögelerin izlerinin etkisinde rastgelelik sonucu oluşmuş gibi görünen çalışmalarda, belli bir süreçte oluşan, inceleme ve tasarlama gerektiren kontrollü ilerleyen, aşamalar söz konusu olmuş, kimi zamanda günümüz kentlerinin özünde karşımıza çıkan kontrolsüzlük büyük veya küçük boyutlu olsun farklı biçimlerde, daima mimari betimlemelere atıfta bulunmuştur. Kentlerin özünde karşımıza çıkan yapılar gibi, biçimsel olarak hassas, ritmik yapılandırılmış, aynı zamanda anlaşılması zor, geçici, tesadüfi ve sürprizli çalışmalar ile izleyiciyi gördüklerini yeniden değerlendirmeye teşvik etmiştir. Sanatçı resimlerinde kolaj veya baskı tekniklerini kullanmamasına rağmen, fotoğrafik bir katmansallık etkisi deneyimi yaşatır (Görsel 6) (Özçelik,2019:70). Tolon, çalışmalarında sıklıkla başvurduğu farklı materyallerden oluşan katmanlar aracılığıyla, bellek yoklaması yapmıştır. Bu yoklama, dönüşen kentin, yiten peyzajın, yok olan doğanın, onlara gömülerek kaybolan belleğin çağrışımlarını temsil eder şekilde olmuştur (Özçelik,2019:71). Tolon'un çalışmalarında, günümüz kentlerinin, insanı yalnızlaştıran, ayrıştıran yapısına atıfta bulunur düzlemde figürsüz manzaralar temel konu haline gelmiştir.

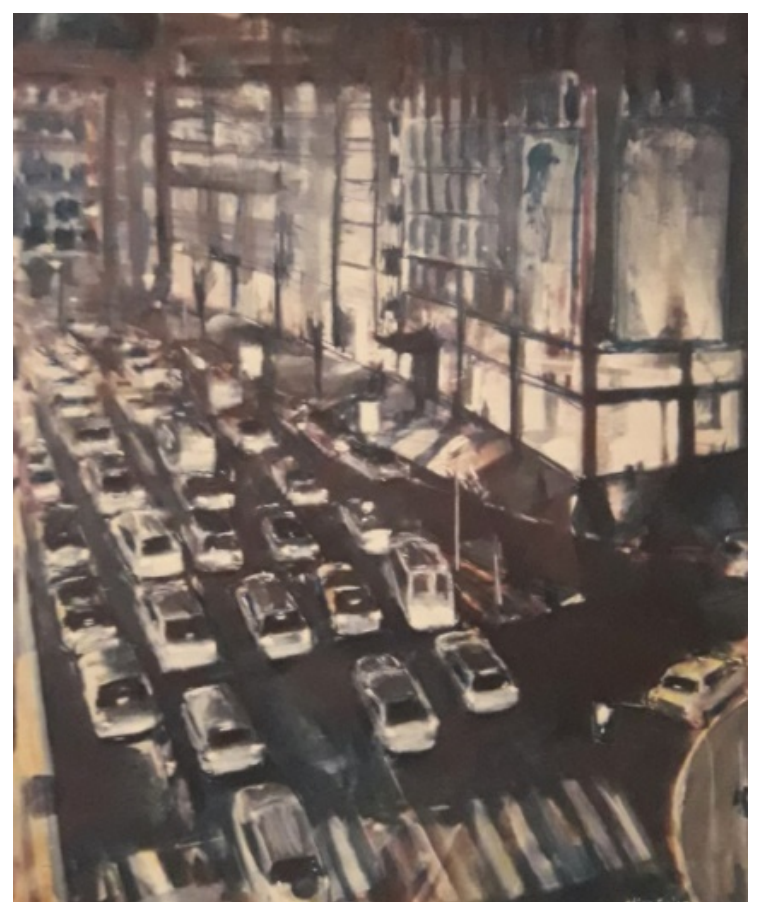

Görsel 7. Altan Çelem, "Nişantaşı", 150 cmx130 cm, Tuval üzerine yağlı boya, 2010 (Zeytinoğlu, 2011)

Günümüz kentleri, irili ufaklı yapıları, yıkılıp tekrar yapılan binaları, Çelem'in eserlerinde çıkan halinden de çıkarım yapabileceğimiz üzere yoğun trafiği ile modern yaşamın getirileriyle birçok uyaranı içinde barındırmaktadır. Günümüzde resimsel serüvenine kent ile ilgili imgeleri dahil eden bir çok sanatçı arasında Altan Çelem, kent ile ilişkisini sosyolojik yaşantının canlı organizmaları üzerinden irdelemiştir. Karşılaşılan kent görünümleri hareket halindedir. Kentin hızı, yoğunluğu, kalabalığı, mimarisi, trafiği sanatçının eserlerinde yer almıştır (Görsel 7). Sanatçı, tarihin çeşitli dönemlerinde aldığı isimlerin yanında küresel kent, kozmopolit kent, modern dünya kenti gibi sıfatların yakıştırıldığı kenti, İstanbul'u eserlerine konu edinmiştir (Özçelik,2019:74). Kentsel göstergeleri kişisel plastik sürecinde yağlıboya ile muğlak bir tonlamayı tercih ederek sunan sanatçı, orada varlığını hissettiren, kat kat perdeler arkasındaymış gibi görünen silik, hızlıca 
resmedilmiş gibi duran ama çok ustaca ve yerinde dokunuşlarla, tuşlarla bezenmiş eserler sunar. Sanatçı kentin göstergelerini izlenimcilerin duyumsallığında, dışavurumcuların keskinliğinde büyük firça vuruşlarıyla, kentin içinde barındırdığı mevcut karşıtlıklar üzerinden, boyanın plastik yoğunluğundan ziyade izleyenin zihnindeki bellek ile tamamlanan eserler üretir. Kurulan resimsel ilişki kentin çekiciliğine kapılmış birinin, o kenti adım adım gezerken gördüklerinden oluşmaktadır ama burada bahsettiğimiz çekicilik turistlerin ilgisini çeken kentin tarihi yerleri ya da manzarası değil, gerçekten kenti kent olarak gösteren, yoğunluğuyla, kalabalığıyla öne çıkan görsellerdir, sanatçının teması bunlardır (Özçelik,2019:74). Kentsel kurgularda yoğun trafik, geniş ve kalabalık caddeler, büyük meydanlar, otoyollar, köprüler, kuleler, fuarlar, havaalanları, birer fragman gibi kesitler halinde yoğunlaşılan alanlar olmuştur. Sanatçı; kente uzaktan bakmak yerine, kentin içine girmiş, kent akışının kargaşasına kendini bırakmıştır. Yol aldığı yerler, şimdiki kentin o kargaşa alanlarıdır (Zeytinoğlu, 2011: 21).

Kentler, artık 19. yüzyıldaki sanayi kenti karakterini çoktan geride bırakmış ve neredeyse kendi kendine kararlar veren, anlık değişkenliklerle dinamikler oluşturan, son derece büyümüş ve değişim hareketlerini hızlandırmış, her köşesinde farklı bir yaşantıyı barındıran bir hale gelmiştir (Özçelik,2019:75). Günümüz kentleri birçok fragmanı içinde barındıran bir yapıya bürünmüştür. $\mathrm{Bu}$ yapıya uygun bir şekilde kent ile alakalı göstergelerden yola çıkarak eserler üreten sanatçılarda kentlerin değişken dinamiklerini yakalayan oluşumlarda bulunmuşlardır.

Kent konusunu ele alan birçok sanatçının yanı sıra, kentsel dinamikleri sanatsal süreçlerine dahil eden bir yapı olarak Hafriyat grubu da karşımıza çıkmaktadır. Hafriyat Grubu kendilerini bir metropol: İstanbul gözlemcisi olarak tanımlamış, güncel kültürün son derece dinamik bir biçimde ortaya çıkarttı̆̆ yeni simgeleri, o simgelere ait bağlamların ve söz konusu bağlamlar dizisinin yarattığı pratik yaşam tanımının peşinde olmuştur (Zeytinoğlu, 2004:7).90'larda ortaya çıkan Hafriyat Grubu kent ile kurdukları sosyolojik bağı, yakın çevrelerinde yaptıkları gündelik gözlemlere dayandırmış ve çeşitli nedenlerle dikkatlerini çeken durumları yansıtmışlardır (Hofmann, 2004: 11). Hafriyat, kent ile ilgilenmiştir çünkü kenti kendi floraları, kendi doğaları olarak görmüş, hayatın sürdürüldüğü yer olarak iletişim kurmanın kaçınılmaz olduğu bir ortam olarak tanımlamışlardır (Güngör, 2016). Günümüz kentleri birçok kültürün bir potada harmanlandığ1 iç içe geçtiği bir yap1 haline dönüşmüştür. Hafriyatçılar da salınarak kentin sokaklarında gezmiş, kent hayatını gözlemlemiş, resimleriyle alt-kesimlerin sesi olmuş, sokağın dilini resme taşıyarak kentin sosyal gerçekliğini yansıtmışlardır (Yıldız, 2008: 440). Göçlerle birlikte gelen hareketliliğin melezleştirdiği kent kültürünün "arada" bir oluşum yaratmasından etkilenen sanatçılar, kentin bu ayrıksı geometrisinden esinlenen işler üzerinde çalışmış; akademik kuramcıların ürettiği, şık ya da steril örneklere mesafeli durmuş ve başka bir gerçekliğe bakmıştır (Karavit, 2004: 15).

Alternatif kent kültürü içinde, İş ve İşçi Bulma Kurumu önünde biriken huzursuz kalabalıklar, oto tamirci dükkanı, ekmek kuyruğu, sıradan-gündelik durumlar, gazetelerde, televizyon haberlerinde sürekli maruz kaldığımız görsel klişeler grup sanatçılarının eserlerinde konu olarak yer almıştır (Özçelik,2019:45). Grubun üyeleri arasında olan Hakan Gürsoytrak ve Antonio Cosentino "var olması gerekenle değil, var olanla" ilgilenerek, kendi plastik süzgeçlerinden geçirerek kent belgeselciliği yapmışlardır (Görsel 8) (Erdemci, 2008: 296). Kentin kazılan, yıkılan, yeniden yapılandırılan alanlarını, sürekli değişen çehresini, kent hayatının ritmini, kaosunu, kentleş(e)me(me)nin farklı tezahürlerini eserlerinde işlemişlerdir (Yıldız, 2008: 440). 


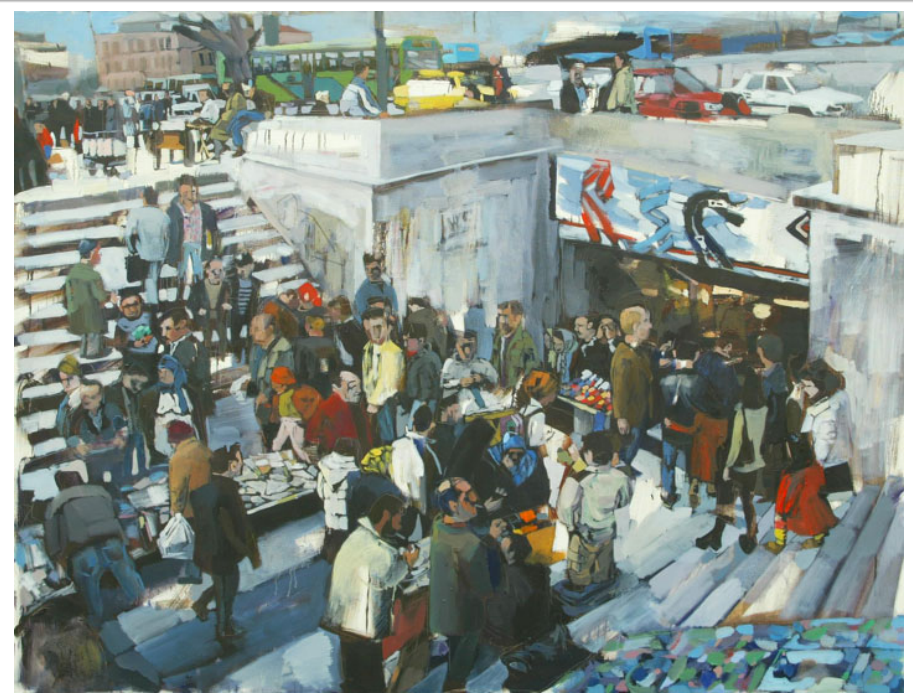

Görsel 8. Hakan Gürsoytrak, "Eminönü Marjnal Sektör”, $127 \mathrm{~cm}$ x $165 \mathrm{~cm}$, Tuval üzerine yağlı boya, 2004 (gursoytrak.com)

Durmadan yenilenen topografik oluşumlar, tahrip edilen ekolojik dengeler, beraberinde oluşan gecekondulaşma ve altyapı sorunu, mimari kurgunun baştan aşağı değişimi, bilinçsiz talanın yön verdiği rant firsatçılığı ve en nihayetinde de sosyal ve kültürel mozaiğin kendi içerisinde çetrefilleşmesi sanatsal düzleme taşınmış, kentsel başkalaşımlar resimsel bağlamda yankı bulmuştur (Çalıkoğlu, 1998: 46; Güngör, 2016). Gürsoytrak'ın kent ile kurduğu buradaki sosyolojik ilişki kentin içinde yaşayan bir birey olmasından da kaynaklanmaktadır. Bu ilişkide sunulan kente dair imgeler, bireysel olarak tecrübe edinilen anlar ve anılardır. Güncel kente bakış sadece bir konu sorunu değildir, bir doku ve duygudur da. Kentlerin yaşam hızı bir televizyon zapçısının tüketim hızı ile eşdeğerdir. Kentin içinde eskinin yerine yeninin geçişi ve sürekli değişim tacizi ile karşılaşılmaktadır. Şehircilik planları, mimari düzenlemeler, derme çatma eklemeler, sürekli yamalanan binalar ve bitmeyen hafriyat çalışmaları, montajcı sanayinin, yaptakçı zihniyetin göstergesidir. Bundan dolayı eserler bu yamuk geometri, hızın eşiğindeki değişim ve tamamlanmamışlık üzerine kurulmuş, şık bir üslupçuluk yerine dağınık, yamalı ama daha içerden bir tavır ile sunulmaya çalışılmıştır (Gürsoytrak, 2004: 19).

Sanatçı figürleri herhangi bir kurmacaya gerek duymadan kendi doğal ortamlarında kentsel ögeler içinde resmetmiştir. Sanatçı resmettiği çok figürlü kompozisyonlarında, günlük yaşamın aksaklıklarını ve olumsuzluklarını keskin bir gözlem gücüyle, mevcut doğallığıyla, kadrajlanan görüntü bir izleyicinin kendi gözünden sunulmuş gibi, izleyende olaya müdahale etme isteği uyandıracak şekilde, adeta belgelemiştir (Özçelik,2019:46). Sanatçının konu seçkileri tamamıyla dış dünya ait olup, dıştan gelen uyaranlarla biçim bulmuştur (Çalıkoğlu,1999a: 42). Eserlerde resmedilen kentsel örgü her gün içinde hayatın karmaşası, yoğunluğu arasında gözümüzden kaçırdığımız gündelik hikayeler olarak sunulmuştur (Rona, 2002: 92). Sanatçı 21.yy kent yaşamını, güncel ve çarpıcı olayları ile ele alırken, değişkenlik ve geçicilik duygularını izleyiciye aktarmaya çalışmıştır. 


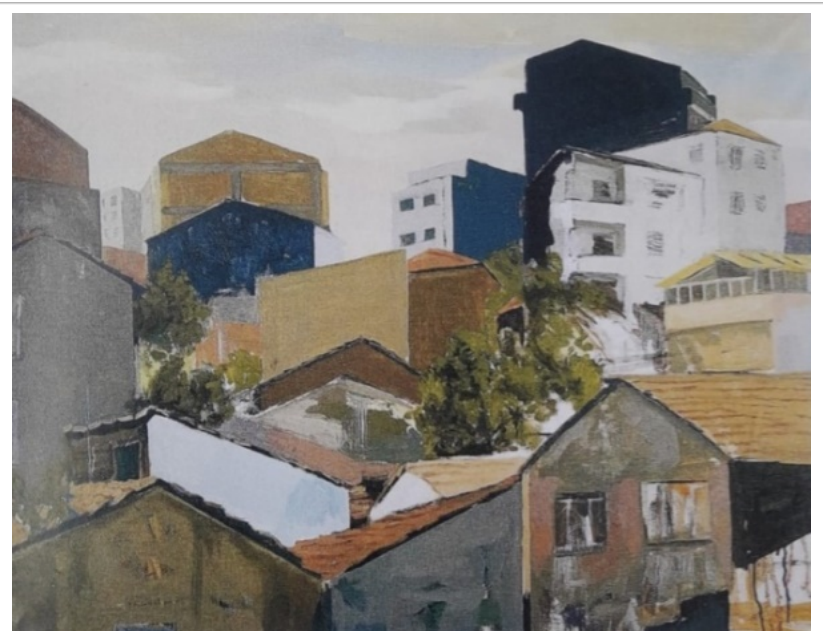

Görsel 9. Antonio Cosentino, "Bomonti 1", $80 \mathrm{~cm}$ x $120 \mathrm{~cm}$, Tuval üzerine yağlı boya, 2003 (Rona, 2004)

Türkiye'de 1960'ların ortasında yaygınlaşmaya başlayan "kat mülkiyeti" yasası ile kentsel görünümler o günlerden günümüze devinen bir yapıda düzensizlik içinde oluşmuştur. Yıllar boyu, sürekli inşaat halinde olan İstanbul'un durmaksızın değişen çehresinde kentsel görüntüler sergilenmiștir, Cosentino tam da bu süreçlerde yaşayan bir kuşaktan olup, değișimleri gözlemleme firsatı bulan bir sanatçı olmuştur (Rona, 2004: 18). Grubun çekirdek kadrosunun üyelerinden olan Antonio Cosentino'nun eserlerinde de gündelik hayattan, bireysel hafizasının diplerinden ve de içinde hayatını sürdürdüğ̈̈ kentin görsel imgelerinden süzülerek gelmiş olan sayısız anlatıma yer verilmiştir (Özçelik,2019:50). Nostaljik şehir dokusu, bellek ve anı çağrışımlı bir doğa özlemi, kent gerçeğine ilişkin sosyolojik bir bakış, bu başlıklar onun sanatının ana temalarını oluşturmuştur (Çalıkoğlu, 2001: 290). Cosentino'nun 90'ların sonlarındaki çalışmalarında kent dokusunu ele aldığı resimleri olmuş, 2000'li y1llara tarihli resimlerinde ise arasında özellikle figürsüz kent görünümlerinde bulunduğu yorumlamalar öne çıkmıştır (Özçelik,2019:52). Sanatçının geniş renk lekeleriyle oluşturduğu apartmanlaşan gecekondu yığınlarında düz ve geniş renk alanlarını kullandığı görülmüştür. Özellikle Bomonti çevresinden gerçekleştirdiği bu resimlerinde dingin bir renk anlayışıyla binaların karmaşası sergilenmiştir. Omuz omuza vermiş askerlik anı fotoğrafı çeken bireylerin kafalarını göstermeye çalışarak itişe kakışa poz verdikleri kareler gibi düzensiz bir şekilde dizilen binalar ile sanatçı kent dokusunun çarpık gelişimini yerleşikliğin verdiği bir düzen duygusuyla vurgulamaya çalışmış, kentsel görünümlerin değişimini eserlerine tüm göstergeleriyle taşımıştır (Rona, 2004: 18) (Görsel 9).

\section{Sonuç}

Kentler, uygarlı̆̆ın ve toplu yaşamanın tanımını barındırdığından beridir, insan hayatının sığınma, hayatta kalma ihtiyaçlarını karşılamaktadır. Bireyin içinde bulunduğu bu yaşam alanları zamanla sadece içinde yaşanılan bir mekan olmanın yanında, bir kimlik göstergesi de olmaya başlamıştır. Kimlik kazanan kentler; fiziki ve tarihsel değişkenlere göre bakıldığında kimi zaman dini yapılarıyla, kimi zaman ihtişamlı binalarıyla kimi zamanda içerdiği fiziki kurgusal yapılanmasıyla içinde yaşayan bireylerden biri olan ressamın firçasına konu olmuştur.

Araştırma çerçevesinde ele alınan eserlerden de anlaşılacağı üzere; çağının çocuğu olarak kendi çağına özgü olanı ifade eden dönemin sanatçıları (Hoca Ali Rıza, Salih Bey, Fehmi Bey) Osmanlı dönemi kent yerleşimlerini, sosyolojik yaşantısını ve kent yapılanmasını eserlerine taşımıştır(Albayrak, 2012:75). Bu dönem eserlerindeki betimlemeler, dönemin sanatsal dinamikleri gereği gerçekçi ve izlenimci düzlemde oluşan bir üslup anlayışında seyretmiş, sanatın görüneni yansıtma kaygısı güden idealize biçimlerinden ileri gidememiştir. Çalışmada sunulan donelerden de anlaşılacağ 1 gibi Osmanlı dönemi kentleri dönemin mimari anlayışı ve şehirleşme politikası 
dahilinde, evlerin az katlı oluşuyla, yatay bir görünüme sahiptir. Günümüzdeki dikey yapılanmanın aksine Osmanlı'nın yatay düzlemdeki kent yapılanmasının o dönemde üretilen eserlere de aynı şekilde yansıdığı ve kaynaklık ettiği görülebilmektedir. Buradaki çıkarımın denklemindeki sebepsonuç ilişkisi Osmanlı dönemi mimarisinin fiziki yapısı ile toplumun içinde yaşayan ressamların içerisinde bulundukları sanatsal anlayış çerçevesinde, mevcut göstergelerden yola çıkarak eserler üretmesi şeklinde açıklanabilir. Yani Osmanlı dönemi kentlerinin görünümlerini sanatsal sürecine dahil eden ressamlar mevcut kentsel düzlemde karşılaştığı doneleri, -sözgelimi en yüksek yapı olan camileri, toprak yolları, iki-üç katı geçmeyen ahşap evleri, mahalle çeşmeleri- eserlerine aktarmışlardır.

Araştırmada incelenen eserler ve sanatçılar dahilinde yapılan çıkarımlara göre bakıldığında; Osmanlı dönemi kent görünümleri ile günümüz kent görünümleri arasında özellikle fiziksel, toplumsal, sosyolojik ve mimari bağlamlarda değişkenlikler söz konusu olmuştur. Günümüz kentleri büyümüss, Osmanlı dönemi kentinde sayllabilecek görsel uyaranlar sokak lambaları, evler, camiler şeklinde bir elin beş parmağını geçmeyecek düzlemde iken, hem fiziksel hem de kitlesel bağlamda genişleyen kentlerimizde artık, tramvay, metro, havaray bunların telleri, direkleri, istasyonları, ara sokaklar, caddeler, otoyollar, köprüler, bu platformlarda yer alan, arabalar, kamyonlar, tırlar, boğazdan geçen yük gemileri, vapurlar, sahil güvenlik botları, irili ufaklı özel yatlar, gecekondular, alışveriş merkezleri, plazalar, sıradan apartmanlar, yalılar, trafik levhaları, reklam panoları vs. bir çok gösterge ile dolup taşmış, değişmiştir.

Geçen yüzyılla oluşan kentsel farklılar gibi sanatçılarda farklılaşmış, sanat anlayışı da değişime uğramıştır. Günümüz ressamının içinde birçok dinamiği barındıran farklı düzlemlerde veriler sunan kentsel görünümleri eserlerine taşıdığ 1 görülmüştür. İçinde dolaşan herhangi bir vatandaş için değer atfedilmeyen binalar, sokaklar, sokak lambaları, yoğun trafik içindeki arabalar ve oluşturduğu kurgular, sanatçı için resimsel düzleminin çok önemli sanatsal ögeleri olmuştur. Oluş sürecinde de, dönemin modern sanat akımları içindeki üslup farklılıkları gözetilerek yorumlama sürecine girilmiştir. Günümüz sanatçısı kentsel biçimleri eserlerine taşırken özgün yorumlama dokunuşlarını ve duyuşsal süreçlerini de dahil etmiştir. Araştırma içinde ele alınan (Mustafa Duymaz, Canan Tolon, Altan Çelem, Hakan Gürsoytrak, Antonio Cosentino) sanatçıların eserlerinde var olan kent; Osmanlı Dönemi kentsel görünümlerini eserlerine taşıan dönem ressamlarının aksine benzetme kaygısı ile görüneni yansıtma arzusunun ilerisinde bir düzlemde oluşmuş, sanatçılar görünen kentin donelerinden yola çıkarak kendi kentlerini eserlerinde oluşturmuşlar, eleştirel bir dille bireysel bakış açılarını mental, duygusal süzgeçlerinden geçirerek dışa vurmuş, günümüz kentlerinin görünümlerini plastik süreçlerinde konu edinmişlerdir.

Elde edilen veriler doğrultusunda, içinde yaşadıkları zamanın, ortamın gerçeklerini yansıtan sanatçıların resimleri karşılaştırıldığında, özün her çağda, her dönemde ve her sanatçıda bambaşka bir dille karşımıza çıktığı görülmüştür. Sanatçılar içinde bulundukları döneme göre; birçok farklı sanatsal eğilimle, yaratma süreci içerisinde geçerli olan toplumsal ve kültürel değerleri ortaya koyma, değiştirme ve geliştirme uğraşı içerisinde yapıtlarını üretirler (Edeer, 2015: 29). Sanatsal düzlemdeki anlatımlar içinde karşımıza çıkan kent, dönemsel olarak benzetme kaygısı güdülerek ya da güdülmeyerek kavramsal bir öge, resimsel bir unsur olarak yerini almıştır.

\section{Kaynakça}

Albayrak, M. (2012). Estetik'in serüveni. Akçağ yayıncılık.

Antmen, A. (2002). Canan Tolon sergisi. Türkiye sanat yıllığı 3, Yılmaz Ofset ve Matbaacılık.

Çalıkoğlu, L. (1998). Cumalı sanat galerisi 25. yılında. Milliyet sanat dergisi, (429), 44-46. Doğan Medya. 
Çalıkoğlu, L. (1999a). Süper Hafriyat iş başında, Milliyet sanat dergisi, (457), 40-42. Doğan Medya.

Çalıkoğlu, L. (2001). Kimliğin bulgulanması çağdaş olma isteği. 20.yy. ikinci yarısında Modern Türk sanatı, Modern Türk, 24-32. İstanbul sanat müzesi vakfı yayınları.

Doğru, H. (1995). 18. yüzyıla kadar Osmanlı kentlerinin sosyal ve ekonomik görüntüsü. Anadolu üniversitesi yayınları.

Edeer, Ş. (2015). Yüzün bakış1, Türmatsan organize matbaacılık.

Erdemci, F. (2008). Büyüyü bozmak, yeniden-yön vermek. Modern ve ötesi:1950-2000, 255305. İstanbul Bilgi Üniversitesi Yayınları.

Güngör, O. (2016). Antonio Cosentino ile Hafriyat Üzerine. Röportaj http://istanbulmuseum.org/artists/antonio\%20cosentino.html (Erişim tarihi:16.04. 2018) 10-14.

Gürsoytrak, H. (2004). Yalan Dünya'da Hafriyat. Yalan Dünya Sergisi kataloğu, 18-24.

Hofmann, J. (2004) Yerelden Evrensele ve Oradan Geriye.Yalan Dünya sergisi kataloğu,11-14.

Karavit, C. (2004). Hafriyat'ın Yalan Dünyası. Yalan Dünya sergisi kataloğu, 14-18.

Kılıçbay, M. A. (2000). Şehirler ve kentler. 2. Baskı. İmge Kitabevi Yayınları.

Özbilgen, E. (2014). Bütün yönleriyle Osmanlı, Adab-1 Osmaniye. 6. Baskı. İz yayıncılık.

Özcan, K. (2006). Anadolu'da Selçuklu kentler sistemi ve mekansal kademelenme, cilt 23, (2), jfa.arch.metu.edu.tr (13.04.2017).

Özçelik, N. (2019). 1980’den günümüze çağdaş Türk resminde kent imgesi, (Yayın no: 604365), [Sanatta yeterlilik tezi, Anadolu Üniversitesi]. Açık. https://tez.yok.gov.tr/UlusalTezMerkezi/tezSorguSonucYeni.jsp

Rona, Z. (2004). Antonio Casentino/Beton denizi. Türkiye sanat ylllığı 5, 18-19. Y1lmaz Ofset ve Matbaacilik.

Shaw, S. J. (1994). Osmanlı İmparatorluğu ve modern Türkiye. (Çev. M. Harmancı) 2. baskı, E Yayınları.

Tek, Şinasi (2014). Ufka veda,/Mustafa Duymaz, Galeri/miz kişisel sergi kataloğu, 2-3, Yunus Matbaacilık.

Yayıntaş, A. (2008). Canan Tolon. Modern ve ötesi:1950-2000, 404-409, İstanbul Bilgi Üniversitesi Yayınları.

Yıldız, E. (2008). Hafriyat. Modern ve ötesi:1950-2000, 440-449, İstanbul Bilgi Üniversitesi Yayınları.

Zeytinoğlu, E. (2004). Yer'in Altını Üstüne Getirmek: Hafriyat. Yalan Dünya sergisi kataloğu, 6-10.

Zeytinoğlu, E. (2011). Altan Çelem'in resimleri üzerine. 9-61, Teşvikiye sanat galerisi yayınları. 